\title{
Association between asthma and female sex hormones
}

\section{Associação entre asma e hormônios sexuais femininos}

\author{
Raquel Prudente de Carvalho Baldaçara', Ivaldo Silva" \\ Universidade Federal do Tocantins (UFT), Palmas (TO), and Universidade Federal de São Paulo (Unifesp), São Paulo, Brazil
}

'MD. Assistant Professor, Medicine, Universidade Federal do Tocantins (UFT), Palmas (TO), Brazil. "MD, PhD. Adjunct Professor, Gynecology, Universidade Federal do São Paulo (SP), Brazil.

\section{KEY WORDS:}

Asthma.

Gonadal steroid hormones.

Women.

Contraceptives, oral.

Cytokines.

\section{PALAVRAS-CHAVE:}

Asma.

Hormônios sexuais.

Mulheres.

Anticoncepcionais orais.

Citocinas.

\begin{abstract}
CONTEXT AND OBJECTIVE: The relationship between sex hormones and asthma has been evaluated in several studies. The aim of this review article was to investigate the association between asthma and female sex hormones, under different conditions (premenstrual asthma, use of oral contraceptives, menopause, hormone replacement therapy and pregnancy).
\end{abstract}

DESIGN AND SETTING: Narrative review of the medical literature, Universidade Federal do Tocantins (UFT) and Universidade Federal de São Paulo (Unifesp).

METHODS: We searched the CAPES journal portal, a Brazilian platform that provides access to articles in the MEDLINE, PubMed, SciELO, and LILACS databases. The following keywords were used based on Medical Subject Headings: asthma, sex hormones, women and use of oral contraceptives.

RESULTS: The associations between sex hormones and asthma remain obscure. In adults, asthma is more common in women than in men. In addition, mortality due to asthma is significantly higher among females. The immune system is influenced by sex hormones: either because progesterone stimulates progesterone-induced blocking factor and Th2 cytokines or because contraceptives derived from progesterone and estrogen stimulate the transcription factor GATA-3.

CONCLUSIONS: The associations between asthma and female sex hormones remain obscure. We speculate that estrogen fluctuations are responsible for asthma exacerbations that occur in women. Because of the anti-inflammatory action of estrogen, it decreases TNF-a production, interferon- $y$ expression and NK cell activity. We suggest that further studies that highlight the underlying physiopathological mechanisms contributing towards these interactions should be conducted.

\section{RESUMO}

CONTEXTO E OBJETIVO: A relação entre os hormônios sexuais e a asma tem sido investigada em diversos estudos. Esta revisão tem como objetivo descrever a relação entre hormônios sexuais (endógenos e exógenos) e a inflamação nas vias aéreas, especialmente na asma, em eventos diferentes (na asma pré-menstrual, durante o uso de anticoncepcionais, na menopausa, no uso de terapia hormonal e na gestação).

TIPO DE ESTUDO E LOCAL: Revisão narrativa da literatura médica, Universidade Federal do Tocantins (UFT) e Universidade Federal de São Paulo (Unifesp).

MÉTODO: Pesquisamos o Portal de Periódicos Capes, uma plataforma brasileira que fornece acesso a artigos nas bases de dados MEDLINE, PubMed, SciELO e LILACS. Os descritores utilizados foram asma, hormônios sexuais, mulheres e uso de anticoncepcionais, com base no "Medical Subject Headings".

RESULTADOS: As associações entre hormônios sexuais e asma ainda permanecem obscuras. Em adultos, a asma é mais frequente em mulheres do que em homens. Além disso, a mortalidade por asma é significativamente maior no sexo feminino, destacando-se que o sistema imunológico sofre influência de hormônios sexuais, seja porque a progesterona estimula o fator bloqueador induzido pela progesterona e citocinas Th2 ou porque contraceptivos derivados de progesterona e estrógeno estimulam o fator de transcrição GATA-3.

CONCLUSÕES: A associação entre asma e hormônios sexuais femininos permanece obscura. Nós especulamos que as flutuações do estrogênio são responsáveis pelas exacerbações da asma que ocorrem nas mulheres. Devido à ação anti-inflamatória do estrogênio há redução da produção de TNF-a, da expressão do interferon- $\gamma$ e da atividade das células NK. Sugerimos que sejam realizados novos estudos para esclarecer os mecanismos fisiopatológicos dessas interações. 


\section{INTRODUCTION}

Asthma is a heterogeneous process that displays considerable phenotypic variability and affects 300 million people globally. ${ }^{1,2}$ It is characterized by the presence of inflammation, hyperresponsiveness and reversible airway obstruction. It is considered to be a public health problem that affects $21 \%$ of the Brazilian population. ${ }^{3,4}$ In Brazil, the mortality rate due to asthma among women is 0.241 per 100,000 inhabitants, whereas among men, it is 0.193 per 100,000 inhabitants. ${ }^{5}$ Among adults, epidemiological studies have demonstrated that the prevalence of asthma is higher among females than among males. ${ }^{6-8}$

The relationship between sex hormones and asthma has been evaluated in several studies. ${ }^{9,10}$ Sex-related differences in the risk, incidence and pathogenesis of a variety of lung diseases exist in humans. ${ }^{11}$ Among children, the prevalence is higher in boys than in girls. ${ }^{12}$ Interestingly, after puberty, the frequency and severity of asthma increase among girls, such that it becomes more common among women by the age of 20 years. ${ }^{13,14}$ After the menopause, the difference in asthma prevalence between men and women decreases. ${ }^{14}$ Thus, in the United States, $65 \%$ of all deaths due to asthma occur among women. ${ }^{11}$

The current paradigm for the pathogenesis of asthma is directly related to gene-environment interaction. Production of Th2 cells (T helper 2) involves the $5 \mathrm{q} 32$ region, which is located on the long arm of chromosome 5, in a cluster of genes encoding IL-4 (interleukin 4), IL-5 (interleukin 5), IL-13 (interleukin 13) and IgE (immunoglobulin E) levels. ${ }^{15}$ The transcription factors that relate to increased Th2 cytokine levels include STAT-5 (signal transducer and activator transducing-5) and GATA-3 (a transcription factor that promotes differentiation of Th2 cells from naïve T lymphocytes). GATA-3 stimulates growth of Th2 cells and inhibits differentiation to Th1 (T helper 1). ${ }^{16,17}$ T lymphocytes are important effector cells in relation to asthma, and activation of Th2 cells is considered to be important, especially in cases of asthma relating to atopy. However, immune responses to Th1 lymphocyte activation may be responsible for epithelial changes and activation of airway smooth muscle. In addition, as the disease becomes chronic, it may cause activation of Th1 lymphocytes with increased TNF- $\alpha$ expression (tumor necrosis factor) and IFN- $\gamma$ (interferon gamma). In nonatopic asthma, a neutrophil inflammatory process may occur. ${ }^{18}$

Tregs (regulatory $\mathrm{T}$ cells) reduce proliferation and decrease Th2 levels and hence the inflammatory process in asthma cases. ${ }^{19}$ Tregs are essential for induction and maintenance of tolerance against antigens. ${ }^{20}$ In asthmatic patients, Tregs become reduced in number and function. ${ }^{20}$ Recently, other T helper cells were discovered (Th9 and Th17), and these cells are related to the physiopathological process and worsening asthma. ${ }^{21}$ The role of IL-17 in asthma is often investigated in patients with non-IgE-mediated non-atopic asthma with a predominance of neutrophils, because Th17 cell levels correlate with disease severity. ${ }^{22}$
Sex hormones play an important role in respiratory health, and hormone fluctuations may be responsible for exacerbations of asthma in women. Hormone fluctuations occur cyclically in reproductive-age women. For four days after menstruation, follicle-stimulating hormone (FSH), luteinizing hormne (LH) and $17-\beta$-estradiol levels are low. During the follicular phase of the menstrual cycle (days 12-16), progesterone levels remain low, while FSH, LH and 17- $\beta$-estradiol levels reach a peak. Finally, during the luteal phase (days 24-28 of the cycle), FSH and LH levels are low, whereas progesterone and $17-\beta$-estradiol levels are moderately high. ${ }^{23}$ If pregnancy occurs, luteolysis is prevented and the progesterone and 17- $\beta$-estradiol levels remain high. After many years, as follicles are depleted and women reaches menopausal status, their sex hormone concentrations decrease to very low levels. In women using oral contraceptives, the progestin component suppresses secretion of $\mathrm{LH}$, and the estrogenic component suppresses secretion of FSH, thus preventing ovulation. ${ }^{12}$

Asthmatic women need to be monitored for hormonal changes. ${ }^{24}$ In a study conducted by Scichilone that included eight healthy women, the progesterone levels during the menstrual cycle influenced the concentration of nitric oxide in exhaled air (FeNO) and alveolar exhaled nitric oxide (CANO). ${ }^{25}$ There is evidence suggesting that both endogenous and exogenous sex steroids modulate inflammatory processes in the lungs and in smooth muscle tissue during different phases of the hormonal cycle in women. ${ }^{26,27}$

A relationship between sex hormones and inflammatory responses in the lower airways, especially with regard to asthma, has been observed in several studies. ${ }^{9-14}$ However, the mechanism for this interaction remains obscure. Thus, it is very important to review the main findings regarding interactions between sex hormones and to understand the pathophysiological mechanisms of this association.

\section{OBJECTIVE}

To investigate the association between asthma and female sex hormones, at different conditions (premenstrual asthma, use of oral contraceptives, menopause, hormone replacement therapy and pregnancy).

\section{METHODS}

For this narrative review, we searched for articles that addressed association between female sex hormones and asthma regardless of clinical situation, which could encompasse premenstrual period, pregnancy, post-menopause period, use of hormone replacement therapy or oral contraceptives. To do this, we searched the journals in the portal of the Coordination Office for Improvement of High-Education Personnel (Coordenação de Aperfeiçoamento de Pessoal de Nível Superior, CAPES). This is a Brazilian platform that provides access to bibliographic sources 
from various locations around the world, including the following: MEDLINE, PubMed, SciELO, and LILACS. The following keywords were used (based on Medical Subject Headings: https://www.nlm.nih.gov/mesh/): asthma and sex hormones (for the initial search); and women and oral contraceptives (included to refine the analysis). The inclusion criteria were the following: complete articles, published over the last 20 years and written in English or French. The exclusion criteria were the following: items for which the full content was not available, letters to the editor, editorials and articles published in non-scientific journals.

The search was performed in four steps:

1. Keywords search.

2. Preliminary search to include and exclude articles by using their abstracts.

3. Complete articles were read and additional exclusions were made.

4. Synthesis.

\section{RESULTS}

\section{Results from search}

In the initial search, we identified 447 references. However, through the preliminary analysis, only 68 references were selected. Only 16 were original articles. The process of study selection is presented in a flow diagram (Figure 1).

\section{Results from studies included}

\section{Menstrual cycle and asthma}

There is little data about airway physiology and hormonal fluctuations. ${ }^{28}$ Exacerbation of asthma in the form of premenstrual asthma (PMA) affects $30 \%$ to $40 \%$ of women with asthma. ${ }^{29,30}$ PMA was described for the first time by Frank in 1931, who reported on a woman who experienced severe attacks of asthma that occurred before her menstrual period. ${ }^{31}$ Some studies have reported a decrease in pulmonary function during the premenstrual portion of the cycle, with a decreased peak expiratory flow rate. ${ }^{24}$ There is also evidence for increased airway inflammation in patients with PMA, as demonstrated by increased levels of eosinophils in sputum and increased levels of fractionated exhaled nitric oxide. ${ }^{32}$

Tan et al. reported on abnormal regulation of beta2-adrenoreceptors, which was proposed as a possible mechanism for PMA during the period of the cycle when progesterone levels are high. ${ }^{33}$ The peak incidence of PMA complaints is two to three days before the onset of menstruation, but this phenomenon can also occur during both the menstrual and premenstrual intervals. ${ }^{31}$ In a prospective study on 182 female patients with asthma, $46 \%$ of all admissions to emergency departments due to acute asthma occurred during the perimenstrual period. ${ }^{29,34}$ Murphy reported that use of
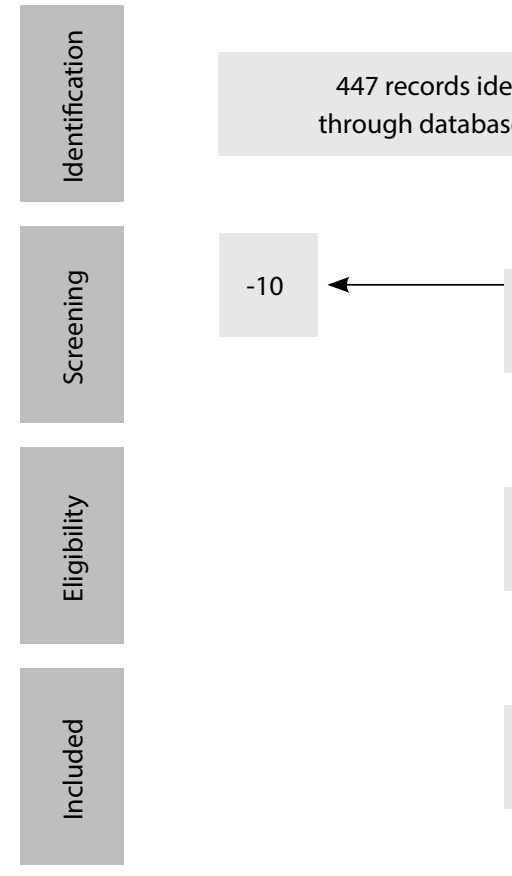

\section{entified} earch

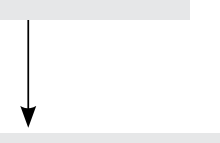

437 records after duplicates removed, screening by title and abstract

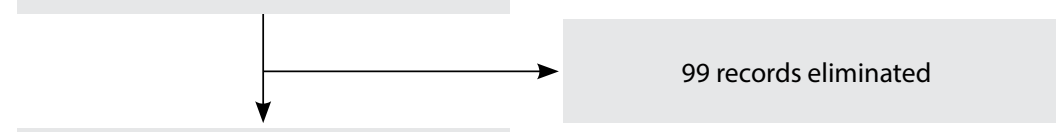

338 records assessed using full text

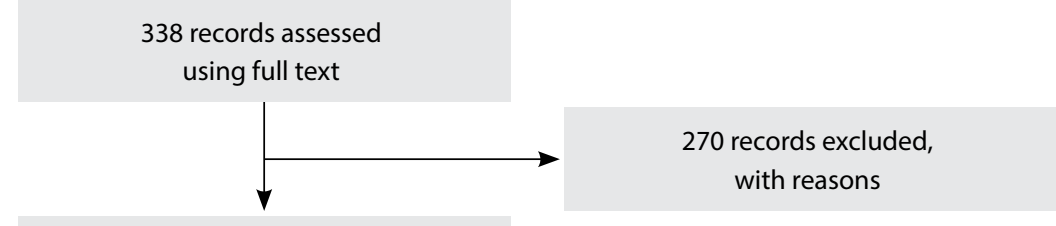

68 records included in qualitative synthesis

Additional records identified through other sources

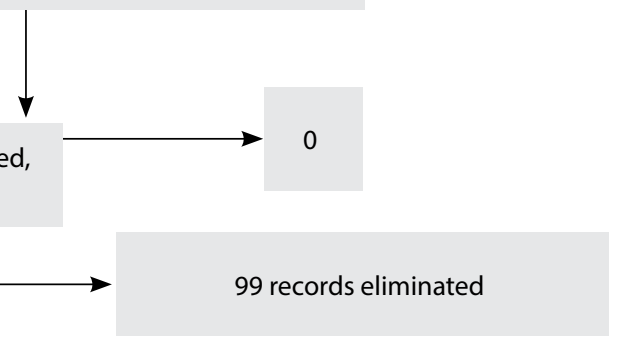

Figure 1. Flow diagram showing study selection for review of studies on association between asthma and female sex hormones. 
oral contraceptives was not protective, and further investigation was required to determine the mechanisms involved in PMA. ${ }^{35}$

A few studies have described treatments for PMA, with conflicting results. Several small series have described use of leukotriene receptor antagonists, exogenous intramuscular progesterone, xanthines, ${ }^{14,24}$ increased doses of inhaled corticosteroids, addition of long-acting beta 2 agonists during the second half of the menstrual cycle, oral contraceptives, a single dose of estradiol (2 mg) during the luteal phase and gonadotropin-releasing-hormone $(\mathrm{GnRH})$ analogues. ${ }^{29}$ However, more studies are needed in order to determine the appropriate treatment for PMA.

\section{Use of hormone contraceptives and asthma}

Contraceptives have frequently been used over the last 50 years for indications including hirsutism, irregular menstruation, dysmenorrhea, polycystic ovarian disease and contraception. Recently, clinical evidence has suggested that use of contraceptives is associated with impaired lung function. ${ }^{7,36}$ Some studies have suggested that use of contraceptives is a risk factor for development or exacerbation of asthma crises. ${ }^{7,36}$ The association between asthma and use of combined contraceptives (estrogen and progesterone) is unclear. The findings in the literature are divergent, given that some studies have reported that estrogen and progesterone improve total lung capacity and reduce the exacerbation of asthma symptoms, such as coughing, wheezing and dyspnea. ${ }^{37-40}$ In a study by Carlson et al., use of oral contraceptives (combined contraceptives) and unopposed forms of estrogens reduced hormone fluctuations and decreased premenstrual asthma. ${ }^{41}$ In a study by Lange, no relationship was found between use of oral contraceptives and asthma. ${ }^{42}$

Erkoçoğlu et al. ${ }^{45}$ found in a survey on 487 women by means of a questionnaire that 196 (40.2\%) reported using oral contraceptives. This use was associated with higher risk of current wheezing among adolescents and young adults, but only among those who had taken the oral contraceptives recently during the previous year. In a study by Macsali et al., ${ }^{7}$ women taking oral contraceptives had more asthma and allergies, but this association was not present in lean women, and there was an additional association with body mass index (BMI).

The association between asthma, obesity and sex hormones has been discussed in the medical literature. Obesity has been correlated with higher estrogen levels and with the enzyme aromatase, which in adipose tissue can convert androgens into estrogens. ${ }^{43,44}$ The Tucson Children's Respiratory Study showed a significant positive association between obesity and wheezing among women who reached puberty when they were under 11 years of age, while obesity was not associated with wheezing among women in whom puberty occurred after they were 11 years old. In the study by Erkoçoğlu et al., there was no evidence of a relationship between BMI and current wheezing. ${ }^{45}$ In a study by Nwaru and Sheikh, hormonal contraceptives reduced exacerbation of asthma and the number of episodes requiring care. That study also showed that overweight and obese women who do not use contraceptives may be at higher risk of asthma. ${ }^{38}$ In a study by Dratva et al., oral contraceptives also appeared to have a protective effect, through decreasing bronchial hyperreactivity. ${ }^{39}$

The cohort study by Jenkins et al. was the first to report an association between parity, use of oral contraceptives and the onset of asthma among women. In this study, women without asthma or wheezing by the age of seven years showed a lower risk of developing asthma, and the risk decreased by $7 \%$ per year of oral contraceptive pill use, independent of parity history. In this group (women without previous asthma or wheezing), the risk of current asthma increased for each birth (odds ratio, OR: 1.50; CI: 1.03-2.23; P = 0.04). Moreover, in the same group, the risk of current asthma was greater among women who were parous, according to the number of births. Women with one birth were at lower risk than nulliparous women. Among women who did have asthma or wheezy breathing by the age of seven years, neither reproductive history nor oral contraceptive pill use predicted current asthma. ${ }^{46}$

Some authors have suggested mechanisms to explain the complex interaction between hormonal contraceptives and asthma. Velez-Ortega reported on the impact of oral contraceptives on generation of induced regulatory T cells (iTregs). ${ }^{37}$ Dysregulation of iTregs plays a major role in the pathophysiology of asthma. In this study, patients taking oral contraceptives showed reduced serum sex hormone levels, and this was associated with higher rates of iTreg induction, better asthma control test scores and a tendency towards lower exhaled nitric oxide (eNO) levels. ${ }^{37}$ On the other hand, Guthikonda et al. ${ }^{47}$ reported that oral contraceptives and early menarche (via exogenous or endogenous hormones) were associated with the DNA methylation level of the Th2 transcription factor gene and GATA-3 and that they increased the risk of asthma among girls, possibly through interaction with genetic variants. This factor may explain how endogenous and exogenous hormones can, in women, increase the prevalence of asthma after puberty. ${ }^{47}$

Another mechanism was reported by Tan et al., who proposed that exogenous progesterone but not estradiol induces paradoxical downregulation and desensitization of $\beta_{2}$-adrenoceptors in asthmatic women, compared with non-asthmatic subjects. ${ }^{48,49}$ Moreover, in another study on eleven women with stable mild to moderate asthma, Tan et al. reported that oral contraceptives did not alter $\beta_{2}$-adrenoceptor regulation and function in stable female asthmatic patients. ${ }^{33}$

Finally, Salam et al. ${ }^{26}$ linked oral contraceptive use and asthma, both of which are common in young women. The 
outcomes from their study demonstrated that among women without asthma, oral contraceptive use was associated with higher risk of current wheezing. In contrast, in the same study, oral contraceptive use was associated with reduced prevalence of current wheezing among women with asthma. This paradox between hormonal contraceptives and immunologically unclear characteristics of sex hormones emphasizes the need for further research and the importance of knowing a patient's medical history, including the gynecological and hormonal characteristics of asthmatic women. ${ }^{26}$

In Table 1, we have summarized the differences between the results from different studies on asthma and hormone contraceptives. In Table 2, we have reported the main outcomes from animal model studies on sex hormones and asthma.

\section{Postmenopausal hormone replacement therapy (HRT) and asthma}

Among women over 50 years of age, the menopause can either coincide with the onset of asthma or be associated with deterioration of a pre-existing asthma condition. ${ }^{50}$ The definition of menopause is the cessation of menstruation for 12 months. ${ }^{51}$ The overall incidence of asthma decreases after the menopause, ${ }^{14}$ although in the Nurses' Health Study, use of hormone replacement therapy (HRT) approximately doubled the risk of asthma, compared with postmenopausal women without HRT. In that study, a 35\% decrease in the incidence of asthma was observed among postmenopausal women without HRT. ${ }^{10}$ In a cohort study, Romieu et al. reported that the increase in the risk of asthma onset at the

Table 1. Animal models for sex hormones and airway inflammation

\begin{tabular}{|c|c|}
\hline Authors & Method \\
\hline $\begin{array}{l}\text { Hellings } \\
\text { et al. }{ }^{63}\end{array}$ & $\begin{array}{l}\text { BALB/c male mice of } 6 \text { weeks of age were sensitized to } \\
\text { ovalbumin (Ova) using intraperitoneal injections. } \\
\text { Medroxyprogesterone or placebo was instilled daily into } \\
\text { the esophagus before and during the inhalatory Ova } \\
\text { challenge phase. }\end{array}$ \\
\hline $\begin{array}{l}\text { Degano } \\
\text { et al. }{ }^{64}\end{array}$ & $\begin{array}{l}\text { Ovariectomized seven-week-old female } \\
\text { Wistar rats received either placebo or } 17 \beta \text {-estradiol (E2) (10 } \\
\text { to } 100 \mathrm{mcg} / \mathrm{kg} / \mathrm{day} \text { ) for } 21 \text { days. They were administered } \\
\text { an aerosol of saline and increasing concentrations of } \\
\text { acetylcholine (Ach) until lung resistance was observed. }\end{array}$ \\
\hline
\end{tabular}
de Oliveira progesterone in allergic lung inflammation. Female Wistar et al. ${ }^{65} \quad$ rats were ovariectomized (Ovx) and then sensitized with ovalbumin $(\mathrm{OA})$. They received estradiol and progesterone.

Adult female BALB/c mice were ovariectomized and implanted with time-release progesterone pallets. They

Mitchell et al. ${ }^{66}$ were housed in filtered air or ETS (environmental tobacco smoke) for 6 weeks and exposed to HDMA (house dust mite allergen) by inhalation.

The authors compared sex differences in the development of airway hyperresponsiveness (AHR) following allergen exposure exclusively via the airways. Ovalbumin was administered via nebulization on 10 consecutive days in 8 to Matsubara $\quad 10$-week male and female BALB/c mice. After methacholine et al. ${ }^{67}$ challenge, significant AHR developed in male mice but not in female mice. Ovariectomized female mice showed significant AHR after 10 days of Ova inhalation. ICl182,780, an estrogen antagonist, similarly enhanced airway responsiveness even when administered 1 hour before the assay.

\section{Results and conclusions}

Progesterone worsened allergic airway inflammation in Ova-challenged mice. Progesterone increased IL-5 levels and elevated airway eosinophilia. Progesterone did not influence allergen-specific IgE production. Progesterone aggravates the phenotype of eosinophilic airway inflammation in mice by enhancing systemic IL- 5 production.

Rats treated with low-dose E2 were less responsive to Ach than rats given either placebo or high-dose E2 were.

Treatment with E2 had a differential, dose-dependent effect on airway responsiveness to Ach.

In Ovx-allergic rats, treatment with estradiol decreased the amount of IL10 and increased the amount of IL-4 produced by bone marrow (BM) cells. Estradiol increased IL $1 \beta$ and TNF $\alpha$ levels in BAL (bronchoalveolar lavage) cells. Progesterone increased the release of IL-10, IL-1 $\beta$ and TNF $\alpha$ by BAL cells and increased the production of IL- 4 by BM cells.

The existence of such dual hormonal effects suggests that hormone therapy in asthmatic postmenopausal women and women who suffer from premenstrual asthma should take into account the possibility that these treatments may worsen pulmonary conditions.

Progesterone alone did not increase mucous cell mass or abundance of eosinophils, but ETS coupled with progesterone exposure resulted in a significant increase in mucous cell metaplasia and increased accumulation of eosinophils in the asthma model.

Progesterone, in the absence of estrogen, exacerbated the airway inflammation and airway remodeling that was induced by the toxicant ETS.

The results showed that 17 beta-estradiol dose-dependently suppressed AHR in male mice. In all cases, airway responsiveness was inhibited by administration of a neurokinin 1 receptor antagonist. The neurokinin 1 receptor antagonist attenuated the effect that the estrogen receptor antagonist had in enhancing AHR in female mice in vivo. Endogenous estrogen may regulate the neurokinin 1-dependent prejunctional activation of airway smooth muscles in allergen-exposed mice. 
Table 2. Hormone contraceptives and asthma

\begin{tabular}{|c|c|c|}
\hline $\begin{array}{l}\text { Authors and } \\
\text { type of study }\end{array}$ & Method & Results and conclusions \\
\hline $\begin{array}{l}\text { Macsali } \\
\text { et al. }^{7} \\
\text { Cross- } \\
\text { sectional } \\
\text { survey }\end{array}$ & $\begin{array}{l}\text { Postal questionnaires were sent to subjects in } \\
\text { Denmark, Estonia, Iceland, Norway and Sweden } \\
\text { from } 1999 \text { to } 2001 \text { (response rate in women, } \\
77 \%) \text {. The analyses included } 5791 \text { women who } \\
\text { were } 25 \text { to } 44 \text { years old, of whom } 961 \text { (17\%) used } \\
\text { oral contraceptives. }\end{array}$ & $\begin{array}{l}\text { Oral contraceptive pills were associated with an increased risk of asthma, asthma } \\
\text { with hay fever, wheezing and shortness of breath, hay fever and } \geq 3 \text { asthma } \\
\text { symptoms. Associations were present. Women using oral contraceptive pills had } \\
\text { more asthma. This was found only in the normal weight and overweight women } \\
\text { and not in lean women, thus indicating an interplay between sex hormones and } \\
\text { metabolic status in their effects on airways. }\end{array}$ \\
\hline $\begin{array}{l}\text { Erkoçoğlu } \\
\text { et al. }{ }^{45} \\
\text { Cross- } \\
\text { sectional }\end{array}$ & $\begin{array}{l}\text { The ISAAC questionnaire was provided to } 487 \\
\text { women between } 11.3 \text { and } 25.6 \text { years of age. } \\
\text { Questions on oral contraceptives were also asked. }\end{array}$ & $\begin{array}{l}\text { In this study, } n=487 \text { (ages ranged from } 11.3 \text { to } 25.6 \text { years old), } 196 \text { ( } 40 \% \text { ) reported } \\
\text { using an oral contraceptive, } 7.4 \% \text { had a diagnosis of asthma from a physician and } \\
10.3 \% \text { of them were active smokers. Young women taking oral contraceptives had a } \\
\text { higher rate of current wheezing, thus suggesting that sex steroids may be important } \\
\text { for respiratory health. }\end{array}$ \\
\hline $\begin{array}{l}\text { Dratva } \\
\text { et al. }^{39} \\
\text { SPALDIA } 2 \\
\text { Cohort }\end{array}$ & $\begin{array}{l}571 \text { women aged } 28 \text { to } 58 \text { years who } \\
\text { had menstrual periods without hormone } \\
\text { treatment were subjected to methacholine } \\
\text { challenge. In a second step, } 130 \text { women } \\
\text { taking oral contraceptives were subjected to } \\
\text { methacholine challenge. }\end{array}$ & $\begin{array}{l}\text { An effect of modification according to asthma status and oral contraceptive use was } \\
\text { found, with a lower odds ratio (OR) among subjects without asthma. An OR }<1 \text { was } \\
\text { found among woman taking oral contraceptives. Oral contraceptives appeared to } \\
\text { have a protective effect through which they decreased bronchial hyperreactivity. }\end{array}$ \\
\hline $\begin{array}{l}\text { Vélez-Ortega } \\
\text { et al. }{ }^{37} \\
\text { Cohort }\end{array}$ & $\begin{array}{l}\text { Thirteen patients were included in this pilot } \\
\text { study. During three distinct phases of their } \\
\text { menstrual cycles, the authors measured } \\
\text { exhaled nitric oxide (eNO) levels, forced } \\
\text { expiratory volume at } 1 \text { second }\left(\mathrm{FEV}_{1}\right) \text {, asthma } \\
\text { control test (ACT) scores, sex steroid hormone } \\
\text { levels in serum, natural Tregs levels in } \\
\text { peripheral blood, and the ability of } \mathrm{CD}^{+} \mathrm{T} \text { cells }\end{array}$ & $\begin{array}{l}\text { Patients taking oral contraceptives showed reduced serum sex hormone levels in } \\
\text { association with higher levels of iTreg induction, better ACT scores and a tendency } \\
\text { to have lower eNO levels. The impact of sex hormones on the capacity of T cells to } \\
\text { polarize towards a regulatory phenotype suggests that regulation of peripheral T cell } \\
\text { lineage plasticity is a potential mechanism that may underlie the beneficial effects of } \\
\text { oral contraceptives among women with asthma. }\end{array}$ \\
\hline
\end{tabular}

Tan et al. ${ }^{33}$

Cohort with intragroup analysis

Tan et al. ${ }^{48}$ Trial

905 women who had undergone menarche were Salam et al. ${ }^{26}$ included. The subjects ranged in age from 13 to Cohort 28 years and had participated in the Children's Health Study. aged 19 to 40 years with stable and moderate asthma. The patients were evaluated while on (day 20 to 21 ) and off (day 5 to 7) oral contraceptives during a 28-day calendar period. Seven nonsmoking females aged 26 years with mild asthma completed the study. They were evaluated through two successive menstrual cycles during the follicular phase (days 1 to 6). They were randomized to receive single oral doses of either ethinyl estradiol or medroxyprogesterone. to generate iTregs ex vivo.

The study population comprised 11 women

Baseline $\mathrm{FEV}_{1}$ did not differ between patients who were on and off oral contraceptives. These did not alter beta2-adrenoreceptor regulation or function in stable female asthmatic patients.

The results showed that exogenous progesterone, but not estrogen, when given during the follicular phase, decreased beta2- adrenoreceptor density and cyclicadenosine monophosphate (AMP) responses in female asthmatics. The beta2adrenoreceptor was abnormally regulated in female asthmatics, and this might be a potential mechanism through which premenstrual asthma could be triggered when progesterone levels are high.

In women without asthma, oral contraceptive use was associated with higher risk of current wheezing. In contrast, oral contraceptive use was associated with reduced prevalence of current wheezing in women with asthma. These associations showed significant trends with duration of oral contraceptive use.

Age at menarche was associated with new-onset asthma after puberty. Compared with women who had their menarche after they were 12 years old, women who reached their menarche before they were 12 years old were at higher risk of asthma after puberty. Because women have a higher risk of asthma after puberty, and because oral contraceptive use is common among young women, clinicians should inform women with asthma about the potential effects of oral contraceptives on asthmarelated respiratory symptoms. 
Table 2. Continues...

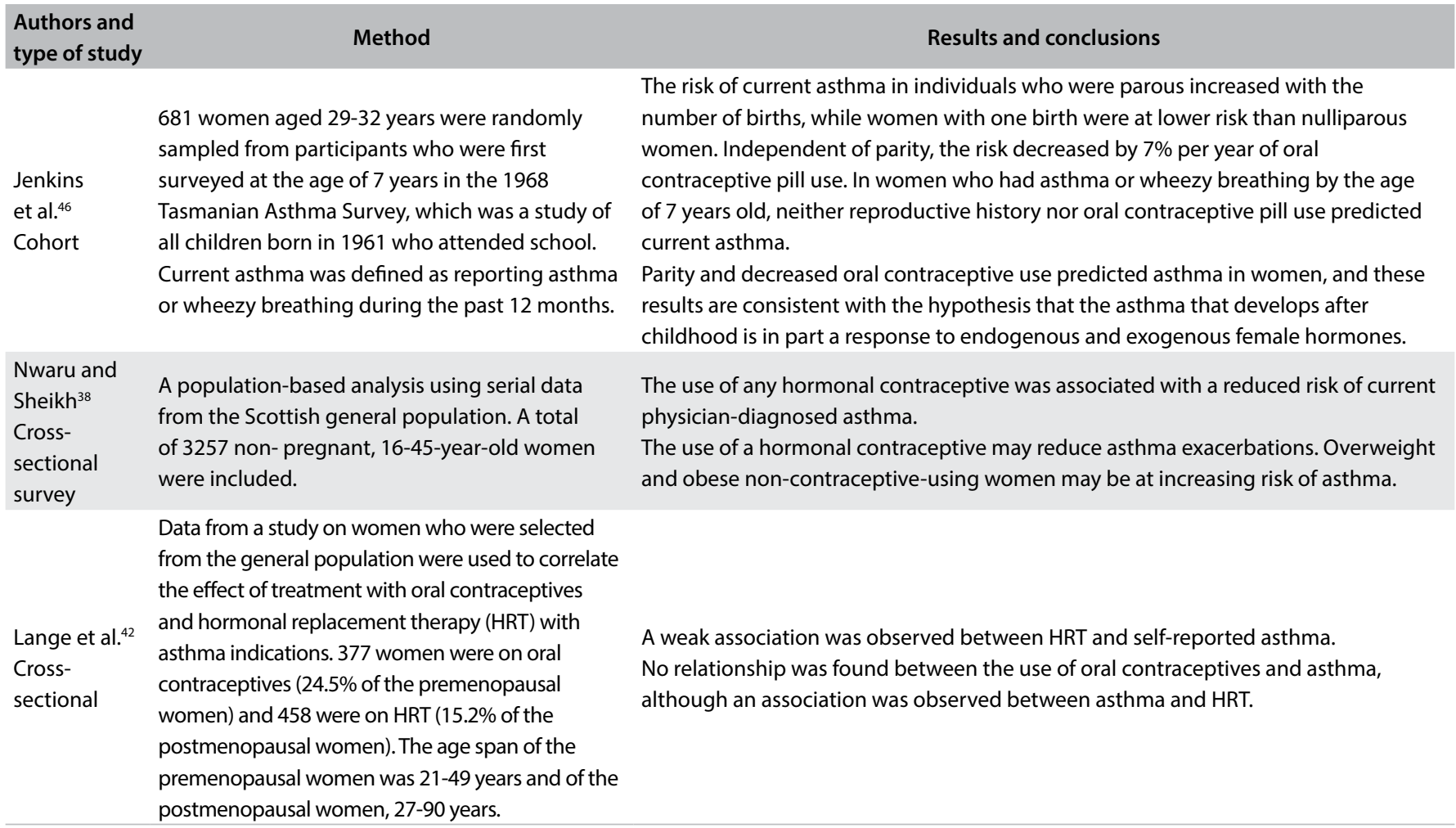

time of the menopause was only significant among women who reported using estrogen alone, especially among those who had never been smokers and those who had had an allergic disease before the onset of asthma. A small increase in the risk of asthma among women who used estrogen/progestogen was found in these subgroups. ${ }^{52}$ In a systematic review and meta-analysis, Zemp et al. found that there was no significant association between menopause with asthma prevalence or incidence except for women who reported using HRT. ${ }^{53}$

In a study by Carlson et al., HRT was associated with better lung function and an increase in forced expiratory volume at one second $\left(\mathrm{FEV}_{1}\right) .{ }^{41}$ The mechanisms that link asthma and the menopause are unclear. After the menopause, FSH and LH levels are elevated, and estrogen levels decrease to the levels observed in patients with surgical oophorectomy, who also show extremely low progesterone levels. The incidence of asthma may be associated with decreased estrogen levels and a protective effect against the relative androgen excess that occurs during the menopausal transition. ${ }^{53,54}$ Clinical studies have indicated that the menopause is associated with exacerbation of pre-existing asthma. Thus, the onset of asthma is characterized by absence of atopy, absence of a family history and associations with urticaria and/or recurrent sinusitis of high severity. ${ }^{23}$ Balzano et al. ${ }^{55}$ showed that eosinophil levels were higher in the induced sputum of menopausal asthmatics, but Foschino Barbaro et al. reported that there were high sputum levels of neutrophils and exhaled interleukin (IL)-6 in women with menopausal asthma. ${ }^{50}$

Few studies have explored the link between the menopause and asthma. Hormonal processes and other factors, including genetics and inflammatory and metabolic characteristics, need to be taken into consideration. Studies have indicated that obesity has an effect on the severity of asthma and that this relationship is modified by gender. Estrogen and leptin levels (which have been correlated with increased airway inflammation in animal models) ${ }^{56}$ are higher in obese women than in non-obese women. ${ }^{54}$ Moreover, obesity has been shown to increase the risk of developing asthma. Interestingly, Gómez Real reported that lean women presented a higher risk of postmenopausal asthma than did obese women using HRT. ${ }^{57}$ This phenomenon can be explained by the notion that in lean women without insulin resistance, the pro-inflammatory effect of estrogens may predominate; while in obese women, the pro-inflammatory effects of estrogens are decreased through insulin resistance. ${ }^{53}$

\section{Pregnancy and asthma}

Asthma affects $3.7 \%$ to $8.4 \%$ of all pregnant women in the United States. Maternal asthma is associated with an increased risk of both 
maternal and fetal adverse perinatal outcomes, ${ }^{58}$ such that $20 \%-30 \%$ of women with asthma experience exacerbations that require medical intervention during pregnancy. ${ }^{43}$ There is also evidence of an increased risk of maternal mortality among some asthmatic women. ${ }^{59}$

A number of the physiological changes that occur during pregnancy can affect asthma status, including mechanical, immunological and hormonal alterations. Estradiol and progesterone levels are highest during pregnancy. ${ }^{60}$ Moreover, one third of women experience improved asthma, while another third of women retain the same asthma status and the remaining third experience worse asthma. Pregnancy is also marked by a state of Th2 dominance, and asthma is generally characterized by $\mathrm{Th} 2$ inflammation. Progesterone receptors are present in large quantities on the surface of lymphocytes, and binding of progesterone to its receptor induces stimulation and release of progesterone-induced blocking factor (PIBF) in a Th2 cytokine expression pattern (IL-4, IL-5, IL-6, IL-9, IL-10 and IL-13). The effects of these proteins are reduced in natural killer (NK) cells, in which expression of IFN- $\gamma$ is decreased. NK cells are mainly observed in the endometrium of pregnant women. ${ }^{12,61}$ During the first trimester of pregnancy, the numbers of circulating and decidual regulatory $\mathrm{T}$ cells (Tregs) increase to promote tolerance at the maternal-fetal interface. ${ }^{62}$

Interestingly, fetal sex may influence asthma. Kwon et al. examined pregnant asthmatic women and found that carrying a female fetus was associated with worse maternal asthma than carrying a male fetus was. ${ }^{60}$ The mechanism that contributes towards this result is unclear, but there is evidence showing that testosterone potentiates the $\beta$-adrenergic-mediated relaxation of bronchial tissues and inhibits responses to histamine. Female sex is associated with higher maternal circulation of monocytes and upregulation of maternal inflammatory pathways. ${ }^{58}$

The mechanisms through which sex hormones influence asthma and the immunological characteristics of pregnancy at the maternal-fetal interface remain obscure, and new studies are needed in order to increase our understanding of and ability to manage asthmatic women.

\section{DISCUSSION}

Studies examining the role of hormonal factors in asthma among women have been conducted on human subjects and animal models, and the results have been described in reviews. In an attempt to understand the influence of sex hormones on pulmonary inflammatory responses, we discuss the main immunological aspects of sex hormones here.

Studies using animal models have demonstrated that both progesterone and estrogen can directly affect the lungs. ${ }^{63-67}$ Sex steroid hormones influence the immune system by acting on the structure and function of the thymus, thereby modulating the activity of B and T cells, mast cells and natural killer cells (NK cells), and affecting phagocytic cells and cytokine production. These hormones act via a variety of receptors (including the estrogen receptors $\mathrm{ER} \alpha$ and $\mathrm{ER} \beta$; and the progesterone receptors PR-A and PR-B), and these steroid receptors have been described as nuclear receptors that act as transcription factors to regulate gene expression. ${ }^{23}$ However, it has been shown that some steroid receptors are located at the plasma membrane (e.g. membrane-bound G-proteincoupled receptors). ${ }^{68,69}$ These receptors are also expressed in the human lungs, such that sex hormones play a role in development of the lungs and androgen receptors are expressed in the mesenchymal and epithelial cells of the lungs.

Gender differences have been observed in relation to development of the lungs. For example, production of surfactants appears earlier in female than in male neonatal lungs, and male preterm infants are at higher risk of experiencing developmental distress syndrome. In addition, before puberty, the prevalence of asthma is higher among boys. ${ }^{43}$ Both male and female fetuses express androgen receptors (AR-A, AR-B) in non-reproductive tissues, with significantly higher numbers of AR-B than AR-A receptors expressed in the lungs. However, few studies have examined expression of androgens in inflammatory airways, and testosterone has been shown to cause relaxation of airway smooth muscles. ${ }^{70}$ Testosterone may increase apoptosis in T cells, thus resulting in a lower percentage of $\mathrm{T}$ lymphocytes in the total pool of lymphocytes in males than in females. ${ }^{12}$

In allergic asthma, airway inflammation is mainly characterized by Th2-mediated processes, including secretion of the cytokines IL-4, IL-5, IL-6, IL-9 and IL-13, secretion of chemokines, regulation of the activation of normal T cells (RANTES), and production of granulocyte macrophage colony-stimulating factor (GM-CSF). In patients with asthma and in allergic animal models (e.g. allergen-challenged mice), bronchoalveolar lavage contains large numbers of eosinophils, M2-polarized macrophages and activated mast cells. In several cases, the numbers of neutrophils in the bronchoalveolar lavage have been found to be higher as a result of Th17-mediated responses and production of IL- $8 .^{68,69}$ The airway epithelium in asthmatic patients recruits innate and adaptive cells via cytokines, including IL-25 and IL-33, and chemokines such as CCL2, CCL17 and CCL20, and it secretes transforming growth factor beta (TGF $\beta$ ), which is responsible for airway remodelling. ${ }^{69}$

The transition of monocytes along the monocyte-macrophage axis is accompanied by upregulation of the $46 \mathrm{kDa} E R a .^{35}$ Activated monocytes and macrophages show increased tumor necrosis factor-alpha (TNFa) secretion. TNFa is a cytokine produced by Th1 cells and is an important mediator in pro-inflammatory responses. Female reproductive phases also influence the production of TNFa by monocytes. In the luteal phase, higher plasma levels of TNFa have been observed. ${ }^{12}$ However, $17 \beta$ estradiol may decrease TNF $\alpha$ levels via an anti-inflammatory effect caused by estrogen. ${ }^{71}$ 
Few studies have examined the effects of sex hormones on the bronchial epithelium. The human bronchial epithelium expresses both ER $\alpha$ and ER $\beta$. In patients with asthma, estrogens facilitate dissociation of endothelial nitric oxide synthetase, which results in activation of the NO pathway, vasodilatation and increased inflammation. ${ }^{72}$ In another study, treatment of bronchial epithelial cells with $10 \mathrm{nM}$ estrogen induced expression of NOS and production of nitric oxide, thus resulting in bronchodilation. ${ }^{69,73}$ In a study by Mandhane et al., among women who were not using oral contraceptives, an increase in progesterone level was associated with an increase in exhaled nitric oxide levels, thus indicating that an inflammatory process was associated with progesterone. ${ }^{74}$

Stimulation of Th2-mediated inflammatory responses and asthma by progesterone has been considered by many studies to represent a typical Th2 disorder. ${ }^{69,75}$ In a study by Loza et al., increased accumulation of IL-13 ${ }^{+} \mathrm{T}$ cells (Th2) was observed in female but not in male asthmatics, and this association was maintained when the analysis was restricted to atopic subjects. ${ }^{75}$ In an animal model, ovariectomized or estradiol antagonist-treated mice developed reduced IL-5 dependent eosinophilia during allergic inflammation. ${ }^{76}$ However, depending on the concentration of estrogen, it may play dual pro and anti-inflammatory roles. ${ }^{64,77}$

\section{CONCLUSIONS}

We have attempted to discuss the characteristics that are affected by sexual hormones during pulmonary inflammatory responses. However, the associations between these factors remain obscure. We speculate that estrogen fluctuations are responsible for asthma exacerbations that occur in women. Because of the anti-inflammatory action of estrogen, as this hormone decreases TNF- $a$ production, it reduces IFN- $\gamma$ expression, and NK cell activity. We suggest that further studies that highlight the underlying physiopathological mechanisms contributing towards these interactions should be conducted.

\section{REFERENCES}

1. Global Strategy for Asthma Management and Prevention (GINA). Available from: http://ginasthma.org/wp-content/uploads/2016/04/ GINA-2016-main-report_tracked.pdf. Accessed in 2016 (Aug 30).

2. National Institute of Allergy and Infectious Diseases. Asthma. Available from: http://www.niaid.nih.gov/topics/asthma/Pages/default.aspx. Accessed in 2016 (Aug 30).

3. IV Diretrizes Brasileiras para o Manejo da Asma [IV Brazilian Guidelines for the management of asthma]. J Bras Pneumol. 2006;32(supl 7):s447-s474.

4. Solé D, Yamada E, Vana AT, et al. International Study of Asthma and Allergies in Childhood (ISAAC): prevalence of asthma and asthmarelated symptoms among Brazilian schoolchildren. J Investig Allergol Clin Immunol. 2001;11(2):123-8.
5. Lotufo PA, Bensenor IM. Temporal trends of asthma mortality rates in Brazil from 1980 to 2010. J Asthma. 2012;49(8):779-84.

6. Siroux V, Oryszczyn MP, Paty E, et al. Relationships of allergic sensitization, total immunoglobulin $\mathrm{E}$ and blood eosinophils to asthma severity in children of the EGEA Study. Clin Exp Allergy. 2003;33(6):746-51.

7. Macsali F, Real FG, Omenaas ER, et al. Oral contraception, body mass index, and asthma: a cross-sectional Nordic-Baltic population survey. J Allergy Clin Immunol. 2009;123(2):391-7.

8. Melgert BN, Ray A, Hylkema MN, Timens W, Postma DS. Are there reasons why adult asthma is more common in females? Curr Allergy Asthma Rep. 2007;7(2):143-50.

9. Barr RG, Wentowski CC, Grodstein F, et al. Prospective study of postmenopausal hormone use and newly diagnosed asthma and chronic obstructive pulmonary disease. Arch Intern Med. 2004;164(4):379-86.

10. Troisi RJ, Speizer FE, Willett WC, Trichopoulos D, Rosner B. Menopause, postmenopausal estrogen preparations, and the risk of adult-onset asthma. A prospective cohort study. Am J Respir Crit Care Med. 1995;152(4 Pt 1):1183-8.

11. Matteis M, Polverino F, Spaziano G, et al. Effects of sex hormones on bronchial reactivity during the menstrual cycle. BMC Pulm Med. 2014;14:108.

12. Bouman A, Heineman MJ, Faas MM. Sex hormones and the immune response in humans. Hum Reprod Update. 2005;11(4):411-23.

13. Varraso R, Siroux V, Maccario J, et al. Asthma severity is associated with body mass index and early menarche in women. Am J Respir Crit Care Med. 2005;171(4):334-9.

14. Kynyk JA, Mastronarde JG, McCallister JW. Asthma, the sex difference. Curr Opin Pulm Med. 2011;17(1):6-11.

15. Wills-Karp M, Ewart SL. Time to draw breath: asthma-susceptibility genes are identified. Nat Rev Genet. 2004;5(5):376-87.

16. Zhu J, Yamane H, Cote-Sierra J, Guo L, Paul WE. GATA-3 promotes Th2 responses through three different mechanisms: induction of Th2 cytokine production, selective growth of Th2 cells and inhibition of Th1 cell-specific factors. Cell Res. 2006;16(1):3-10.

17. Höfer T, Nathansen H, Löhning M, Radbruch A, Heinrich R. GATA-3 transcriptional imprinting in Th2 lymphocytes: a mathematical model. Proc Natl Acad Sci U S A. 2002;99(14):9364-8.

18. Magnan AO, Mély LG, Camilla CA, et al. Assessment of the Th1/ Th2 paradigm in whole blood in atopy and asthma. Increased IFNgamma-producing CD8(+) T cells in asthma. Am J Respir Crit Care Med. 2000;161(6):1790-6.

19. Lowder TW, Kunz HE. Regulatory T Cells in Asthma and Airway Hyperresponsiveness. Journal of Allergy \& Therapy. 2011;S1-002. Available from: http://www.omicsonline.org/regulatory-t-cells-inasthma-and-airway-hyperresponsiveness-2155-6121.S1-002.pdf. Accessed in 2016 (Aug 30).

20. Langier S, Sade K, Kivity S. Regulatory T cells in allergic asthma. Isr Med Assoc J. 2012;14(3):180-3. 
21. Vock $\mathrm{C}$, Hauber HP, Wegmann M. The other T helper cells in asthma pathogenesis. J Allergy (Cairo). 2010;2010:519298.

22. Cosmi L, Liotta F, Maggi E, Romagnani S, Annunziato F.Th17 cells: new players in asthma pathogenesis. Allergy. 2011;66(8):989-98.

23. Balzano G, Fuschillo S, Melillo G, Bonini S. Asthma and sex hormones. Allergy. 2001;56(1):13-20

24. Karpel JP, Wait JL. Asthma in women, Part 3: Perimenstrual asthma, effects of hormone therapy. Journal of Critical IIIness. 2000;15(5):26572. Available from: http://go.galegroup.com/ps/anonymous?id=GAL E\%7CA76609703\&sid=googleScholar\&v=2.1 \&it=r\&linkaccess=fulltex t\&issn=10400257\&p=AONE\&sw=w\&authCount=1\&isAnonymousEn try=true. Accessed in 2016 (Aug 30).

25. Scichilone N, Battaglia S, Braido F, et al. Exhaled nitric oxide is associated with cyclic changes in sexual hormones. Pulm Pharmacol Ther. 2013;26(6):644-8

26. Salam MT, Wenten M, Gilliland FD. Endogenous and exogenous sex steroid hormones and asthma and wheeze in young women. J Allergy Clin Immunol. 2006;117(5):1001-7.

27. Haggerty CL, Ness RB, Kelsey S, Waterer GW. The impact of estrogen and progesterone on asthma. Ann Allergy Asthma Immunol. 2003;90(3):28491; quiz 291-3, 347.

28. Macsali F, Svanes C, Sothern RB, et al. Menstrual cycle and respiratory symptoms in a general Nordic-Baltic population. Am J Respir Crit Care Med. 2013;187(4):366-73.

29. Tan KS. Premenstrual asthma: epidemiology, pathogenesis and treatment. Drugs. 2001;61(14):2079-86.

30. Pereira-Vega A, Sánchez Ramos JL, Vázquez Oliva R, et al. Premenstrual asthma and female sex hormones. J Investig Allergol Clin Immunol. 2012;22(6):437-9.

31. Vrieze A, Postma DS, Kerstjens HA. Perimenstrual asthma: a syndrome without known cause or cure. J Allergy Clin Immunol. 2003;112(2):271-82.

32. Redmond AM, James AW, Nolan SH, Self TH. Premenstrual asthma: emphasis on drug therapy options. J Asthma. 2004;41(7):687-93.

33. Tan KS, McFarlane LC, Lipworth BJ. Beta2-adrenoceptor regulation and function in female asthmatic patients receiving the oral combined contraceptive pill. Chest. 1998;113(2):278-82.

34. SkobeloffEM, Spivey WH, Silverman R, et al. The effect of the menstrual cycle on asthma presentations in the emergency department. Arch Intern Med. 1996;156(16):1837-40.

35. Murphy VE, Gibson PG. Premenstrual asthma: prevalence, cycle-to-cycle variability and relationship to oral contraceptive use and menstrual symptoms. J Asthma. 2008;45(8):696-704.

36. Real FG, Svanes C, Macsali F, Omenaas ER. Hormonal factors and respiratory health in women--a review. Clin Respir J. 2008;2 Suppl 1:111-9.

37. Vélez-Ortega AC, Temprano J, Reneer MC, et al. Enhanced generation of suppressor T cells in patients with asthma taking oral contraceptives. J Asthma. 2013;50(3):223-30.

38. Nwaru Bl, Sheikh A. Hormonal contraceptives and asthma in women of reproductive age: analysis of data from serial national Scottish Health Surveys. J R Soc Med. 2015;108(9):358-71.
39. Dratva J, Schindler C, Curjuric I, et al. Perimenstrual increase in bronchial hyperreactivity in premenopausal women: results from the populationbased SAPALDIA 2 cohort. J Allergy Clin Immunol. 2010;125(4):823-9.

40. Caracta CF. Gender differences in pulmonary disease. Mt Sinai J Med. 2003;70(4):215-24.

41. Carlson CL, Cushman M, Enright PL, et al. Hormone replacement therapy is associated with higher FEV1 in elderly women. Am J Respir Crit Care Med. 2001;163(2):423-8

42. Lange P, Parner J, Prescott E, Ulrik CS, Vestbo J. Exogenous female sex steroid hormones and risk of asthma and asthma-like symptoms: a cross sectional study of the general population. Thorax. 2001;56(8):613-6.

43. Carey MA, Card JW, Voltz JW, et al. It's all about sex: gender, lung development and lung disease. Trends Endocrinol Metab. 2007;18(8):308-13.

44. Weiss ST. Obesity: insight into the origins of asthma. Nat Immunol. 2005;6(6):537-9.

45. Erkoçoğlu M, Kaya A, Azkur D, et al. The effect of oral contraceptives on current wheezing in young women. Allergol Immunopathol (Madr). 2013;41(3):169-75

46. Jenkins MA, Dharmage SC, Flander LB, et al. Parity and decreased use of oral contraceptives as predictors of asthma in young women. Clin Exp Allergy. 2006;36(5):609-13.

47. Guthikonda K, Zhang H, Nolan VG, et al. Oral contraceptives modify the effect of GATA3 polymorphisms on the risk of asthma at the age of 18 years via DNA methylation. Clin Epigenetics. 2014;6(1):17.

48. Tan KS, McFarlane LC, Lipworth BJ. Paradoxical down-regulation and desensitization of beta2-adrenoceptors by exogenous progesterone in female asthmatics. Chest. 1997;111(4):847-51 .

49. Tan KS, McFarlane LC, Lipworth BJ. Loss of normal cyclical beta 2 adrenoceptor regulation and increased premenstrual responsiveness to adenosine monophosphate in stable female asthmatic patients. Thorax. 1997;52(7):608-11.

50. Foschino Barbaro MP, Costa VR, Resta O, et al. Menopausal asthma: a new biological phenotype? Allergy. 2010;65(10):1306-12.

51. Macsali F, Svanes C, Bjørge L, Omenaas ER, Gómez Real F. Respiratory health in women: from menarche to menopause. Expert Rev Respir Med. 2012;6(2):187-200; quiz 201-2.

52. Romieu I, Fabre A, Fournier A, et al. Postmenopausal hormone therapy and asthma onset in the E3N cohort. Thorax. 2010;65(4):292-7.

53. Zemp E, Schikowski T, Dratva J, Schindler C, Probst-Hensch N. Asthma and the menopause: a systematic review and meta-analysis. Maturitas. 2012;73(3):212-7.

54. Zein JG, Erzurum SC. Asthma is Different in Women. Curr Allergy Asthma Rep. 2015;15(6):28.

55. Balzano G, Fuschillo S, De Angelis E, et al. Persistent airway inflammation and high exacerbation rate in asthma that starts at menopause. Monaldi Arch Chest Dis. 2007:67(3):135-41.

56. Shore SA, Fredberg JJ. Obesity, smooth muscle, and airway hyperresponsiveness. J Allergy Clin Immunol. 2005;115(5):925-7. 
57. Gómez Real F, Svanes C, Björnsson EH, et al. Hormone replacement therapy, body mass index and asthma in perimenopausal women: a cross sectional survey. Thorax. 2006;61(1):34-40.

58. Bakhireva LN, Schatz M, Jones KL, et al. Fetal sex and maternal asthma control in pregnancy. J Asthma. 2008;45(5):403-7.

59. Tan KS, Thomson NC. Asthma in pregnancy. Am J Med. 2000;109(9):727-33.

60. Kwon HL, Belanger K, Holford TR, Bracken MB. Effect of fetal sex on airway lability in pregnant women with asthma. Am J Epidemiol. 2006;163(3):217-21.

61. Broide DH. Molecular and cellular mechanisms of allergic disease. J Allergy Clin Immunol. 2001;108(2 Suppl):S65-71.

62. Oertelt-Prigione S. Immunology and the menstrual cycle. Autoimmun Rev. 2012;11(6-7):A486-92.

63. Hellings PW, Vandekerckhove P, Claeys R, et al. Progesterone increases airway eosinophilia and hyper-responsiveness in a murine model of allergic asthma. Clin Exp Allergy. 2003;33(10):1457-63.

64. Degano B, Mourlanette P, Valmary S, et al. Differential effects of low and high-dose estradiol on airway reactivity in ovariectomized rats. Respir Physiol Neurobiol. 2003;138(2-3):265-74.

65. de Oliveira AP, Domingos HV, Cavriani G, et al. Cellular recruitment and cytokine generation in a rat model of allergic lung inflammation are differentially modulated by progesterone and estradiol. Am J Physiol Cell Physiol. 2007;293(3):C1120-8.

66. Mitchell VL, Van Winkle LS, Gershwin LJ. Environmental tobacco smoke and progesterone alter lung inflammation and mucous metaplasia in a mouse model of allergic airway disease. Clin Rev Allergy Immunol. 2012;43(1-2):57-68.

67. Matsubara S, Swasey CH, Loader JE, et al. Estrogen determines sex differences in airway responsiveness after allergen exposure. Am J Respir Cell Mol Biol. 2008;38(5):501-8.

68. Zierau O, Zenclussen AC, Jensen F. Role of female sex hormones, estradiol and progesterone, in mast cell behavior. Front Immunol. 2012;3:169.

69. Keselman A, Heller N. Estrogen Signaling Modulates Allergic Inflammation and Contributes to Sex Differences in Asthma. Front Immunol. 2015;6:568.

70. Chang HY, MitznerW. Sex differences in mouse models of asthma. Can J Physiol Pharmacol. 2007:85(12):1226-35.

71. Ito A, Bebo BF, Jr., Matejuk A, et al. Estrogen treatment down-regulates TNF-alpha production and reduces the severity of experimental autoimmune encephalomyelitis in cytokine knockout mice. J Immunol. 2001;167(1):542-52.

72. Sathish V, Martin YN, Prakash YS. Sex steroid signaling: implications for lung diseases. Pharmacol Ther. 2015;150:94-108.

73. Townsend EA, Meuchel LW, Thompson MA, Pabelick CM, Prakash YS. Estrogen increases nitric-oxide production in human bronchial epithelium. J Pharmacol Exp Ther. 2011;339(3):815-24.

74. Mandhane PJ, Hanna SE, Inman MD, et al. Changes in exhaled nitric oxide related to estrogen and progesterone during the menstrual cycle. Chest. 2009;136(5):1301-7.
75. Loza MJ, Foster S, Bleecker ER, Peters SP, Penn RB. Asthma and gender impact accumulation of T cell subtypes. Respir Res. 2010;11:103.

76. Riffo-Vasquez Y, Ligeiro de Oliveira AP, Page CP, Spina D, Tavares-deLima W. Role of sex hormones in allergic inflammation in mice. Clin Exp Allergy. 2007;37(3):459-70.

77. Straub RH. The complex role of estrogens in inflammation. Endocr Rev. 2007;28(5):521-74.

\section{Sources of funding: None}

Conflict of interest: None

Date of first submission: May 6, 2016

Last received: June 19, 2016

Accepted: June 27, 2016

\section{Address for correspondence:}

Raquel Prudente de Carvalho Baldaçara

Universidade Federal do Tocantins

Quadra 401 Sul, Avenida LO 11, Conjunto 2, Bloco 2

Edifício Palmas Medical Center, sala 504

Plano Diretor Sul — Palmas (TO) — Brasil

Tel. (+55 63) 3217-7288

E-mail: raquel.baldacara@gmail.com 